\title{
The opinions of nurses and physicians related to euthanasia
}

\section{Hemşire ve hekimlerin ötanaziye ilişkin görüşleri}

\author{
Alper Beder ${ }^{1}$, Gül Pınar', Gamze Aydoğmuş ${ }^{2}$, Mahmure Can², Handan Eren², Nihal İşler², Sevinç \\ Y1lmaz ${ }^{2}$, Müberra Birli
}

\begin{abstract}
Objective: The research was conducted to investigate the opinions of nurses and physicians pertaining to euthanasia who are working at Internal Medicine, Surgery and Intensive Care Unit departments at Baskent University Ankara hospital.

Methods: The research is a descriptive one. The sample consisted of 154 nurses and physicians who are working at Internal Medicine, Surgery and Intensive Care Unit departments at Baskent University Ankara hospital and accepted to participate and could be reached. A questionnaire with 30 items was used to collect data to obtain the socio-demographic characteristics and the opinions pertaining to euthanasia of nurses and physicians. Frequencies, mean values and chi-square tests were used in statistical analysis.
\end{abstract}

Results: The participants didn't approve euthanasia with a high ratio however it was determined that almost half of them asserted it as patient's rights of a patient who want his/her death to be fastened and who has no chance to be cured and who are spending the last days of their life with unbearable pain. Except the age groups and marital status there was no significant difference found statistically between the opinions of physicians and nurses regarding euthanasia $(p>0.05)$.

Conclusion: It was stated that nurses and physicians consider not active euthanasia but passive euthanasia as acceptable. J Clin Exp Invest 2010; 1(2): 91-98

Key words: Euthanasia, nurses, physicians, opinion

\section{GİRIŞ}

\section{Problemin Tanımı ve Önemi}

Çağdaş tıbbın, ortalama insan ömrünü uzatması çerçevesinde dikkat çekici iki unsuru vardır. Birinci unsur koruyucu uygulamalarla ortalama yaşam süresinin artmas1, ikincisi ise destekleyici tedavilerle yaşamın son döneminin uzatılmasıdır. Bu iki unsu-

\section{ÖZET}

Amaç: Araştırma, Başkent Üniversitesi Ankara Hastanesi Dahiliye-Cerrahi Servisi ve Yoğun Bakımlarında çalışan hekim ve hemşirelerin ötanazi hakkındaki düşüncelerini belirlemek amacıyla yapılmıştır.

Yöntem: Araştırma tanımlayıcı tiptedir. Araştırmaya katılmayı kabul eden ve ulaşılabilen 154 hekim ve hemşire araştırma grubunu oluşturmuştur. Verilerin toplanmasında, hekim ve hemşirelerin sosyo-demografik özelliklerini ve ötanazi ile ilgili düşüncelerini sorgulayan 30 maddelik anket kullanılmıştır. İstatistiksel analizlerde yüzdelik, ortalama ve ki-kare testleri kullanılmıştır.

Bulgular: Araştırmaya katılanlar ötanaziyi büyük oranda onaylamamakla birlikte, iyileşme olasılığı bulunmayan ve dayanılmaz ağrılar içinde son günlerini geçirmekte olan bir hastanın ölümünün çabuklaştırılmasını istemesinde yaklaşık yarısının hastanın hakkı olarak savunduğu belirlenmiştir. Yapılan istatistiksel analizlerde hekim ve hemşirelerin yaş grubu ve medeni durum dışında ötanaziye yönelik görüşleri arasında istatistiksel olarak anlamlı bir fark bulunmamıştır ( $p>0.05$ ). Klin Den Ar Derg 2010; 1(2): 91-98

Sonuç: Hekim ve hemşirelerin aktif değil ama pasif ötanaziyi kabul edilebilir gördükleri saptanmıştır.

Anahtar kelimeler: Ötanazi, hemşireler, hekimler, görüş

run, özellikle hastalığı ortadan kaldırıcı veya tedavi yapılamayan durumlarda devreye girişi, günümüzdeki ötanazi tartışmalarının çıkış noktasını oluşturmaktadır. ${ }^{1}$

Ötanazi (Euthanasia) eski Yunan dilinde iyi, rahat anlamına gelen 'eu' ve ölüm anlamına gelen 'thanatos' sözcüklerinin birleşiminden 'rahat ve kolay ölüm' anlamına gelmektedir. ${ }^{2,3}$ Bugün yaygın

'Bașkent Üniversitesi Sağlık Bilimleri Fakültesi Hemșirelik ve Sağlık Hizmetleri, Ankara

${ }^{2}$ Başkent Üniversitesi Ankara Hastanesi- Türkiye

Yazıșma Adresi /Correspondence: Yrd. Doç. Dr. Alper Beder, Bașkent Üniversitesi Sağlık Bilimleri Fakültesi Hemşirelik ve Sağlık Hizmetleri Bölümü, Eskișehir Yolu, 20. km. Bağlıca Kampusü, Çayyolu/Ankara, Email: alper@baskent.edu.tr

Geliș Tarihi / Received: 19.07.2010, Kabul Tarihi / Accepted: 10.08.2010

Copyright @ Klinik ve Deneysel Araștırmalar Dergisi 2010, Her hakkı saklıdır / All rights reserved 
olarak kabul edilen tanıma göre ise iyileşmeyeceği ve duymakta olduğu dayanılmaz acıların yaşamının sonuna kadar süreceği tıbben kesin olarak belirlenmiş hastaların yaşamının bilinçli, özgür iradesi ve isteği ile hekimler tarafindan acı çektirilmeden sonlandırılmasıdır. ${ }^{4}$ Genel bir yaklaşımla ötanazi ise; tedavisi olmadığına karar verilen ağrılı/ağrısız hastaların özgür iradeleriyle ya da iradesinin alınamadığ rının, izni ile tıbbi yoldan yaşamına son verilmesi şeklinde tanımlanmaktadır. ${ }^{5}$ Günümüzde tartışılan ötanazi kavramı birçok kişi tarafından aktif ve pasif olarak bilinmesine rağmen bunların yanında istemli, istemsiz, istem dışı, asiste (yardımlı), iç, dış, kazai ve medikal olarak da tanımlanmıştır. Aktif ötanazi, tıbbi yardım ile veya yardımsız, aktif veya direkt yardım ile yaşamının kısaltılmasıdır. Pasif ötanazi; bir hasta veya yaralının hayatını uzatacak yardımlardan vazgeçilmesi veya geri alınmasıdır. ${ }^{6}$

Dünya Hekimler Birliği'nin hasta haklarını içeren Lizbon Bildirgesi'nde (1981) hastanın saygın bir şekilde ölme hakkı bulunduğu kabul edilmiş, ötanaziye karar verme hakkına yeterince bilgilendirilmiş olması koşulu ile sahip olduğu vurgulanmıştır. Ötanazi tartışmaları, Grek-Roma dönemine kadar uzanmaktadır. ${ }^{7}$ Ötanazinin yasallaşmasıyla ilgili gelişmeler 1906 yılında akademik düzeyde ele alınmıştır. Dünya ülkelerinin birçoğunda ötanazi suç kabul edilmektedir. Suçun niteliği ve cezası ülkeden ülkeye değişmektedir. ${ }^{6}$ Gelişmiş toplumlar konuya kendi koşullarına uygunluğuna göre yaklaşmakta; Almanya, İngiltere, Fransa gibi ülkeler uygulamay1 tamamıla yasaklarken, ABD'de hastanın tedavisinin kesilmesi ya da yasam desteğinin kesilmesi sonucu yaşamının sona erdirilmesine (pasif ötanazi) mahkeme kararıyla izin verilmektedir. Günümüzde Hollanda ve Belçika dışında aktif ötanaziyi yasal olarak kabul eden başka bir ülke yoktur. ${ }^{5,6}$ Hukuksal açıdan ele alındığında Türkiye'de ötanazi ile ilgili herhangi bir yasal düzenleme bulunmamaktadır. Ancak, 26.9.2004 tarih ve 5237 Kanun No'lu Türk Ceza Kanunu'nun "Hayata Karşı Suçlar” bölümü incelendiğinde bazı maddelerin aktif ve pasif ötanazi kapsamına girdiği ve suçun işlenmesi halinde müebbet hapis cezasına varan cezaların verilebileceği, kişinin kendi rızası olduğu tespit edilirse hafifletici sebepler devreye girebileceği görülmektedir. ${ }^{8}$ Ayrıca, 1960'dan günümüze yürürlükte olan Tibbi Deontoloji Tüzüğü incelendiğinde de, özellikle madde 11'in aktif ve pasif ötanazi kapsamına girdiği ve ötanaziyi yasakladığı görülmektedir. ${ }^{9}$

Dünyada ve ülkemizde etik ve politik alanlarda tartışmalara yol açan ötanazi, sağlık çalışanları arasında da bireyin yaşamını koruma, sürdürme, iyileştirme görev ve sorumlulukları ile özerkliğe sayg1 ilkesinden kaynaklanan ikilemlere neden olmaktadır. ${ }^{4}$ Özetle ötanazi acılar içindeki bir insana yardım etmeye yönelik yararlı, insani boyutu olan bir eylem olarak değerlendirilse de; etik olarak ve toplumsal yarar açısından bakıldığında kabul edilemez noktalara da sahiptir. Bu açıdan ötanazi ile ilgili tartışmalar dünya çapında çok yönlü olarak devam etmekte ve sağlık çalışanlarının tutumları giderek daha önemli bir hale gelmektedir. ${ }^{4}$ Sağl1k bakımında görev alacak hekim ve hemşirelerin ötanazi konuları ile ilgili görüşlerine yer verilmesi, bu konudaki etik, politik ve yasal sorunların tartışılmas1 açısından önemli görülmektedir.

\section{Çalışmanın Amacı}

Araştırma Başkent Üniversitesi Ankara Hastanesi'nde çalışan hekim ve hemşirelerin ötanazi hakkındaki görüşlerinin incelenmesi amacıyla yapılmıştır.

\section{GEREÇ VE YÖNTEM}

\section{Araştırmanın Şekli}

Tanımlayıcı tipte bir araştırmadır.

\section{Evren ve Örneklem}

Araştırma evrenini, Başkent Üniversitesi Ankara Hastanesi Dâhiliye-Cerrahi Servisi ve Yoğun Bakımlarında çalışan hekim ve hemşireler oluşturmaktadır $(\mathrm{N}=200)$. Araştırma örneklem seçimine gidilmemiş araştırma grubunun tamamına ulaşılması planlanmıştır. 19 Nisan - 04 Haziran 2010 tarihleri arasında araştırmaya katılmayı kabul eden ve ulaşılabilen 92 hemşire ve 62 hekim olmak üzere toplam 154 kişi araştırma grubunu oluşturmuştur.

\section{Bağımlı ve Bağımsız Değişkenler}

Bağımsız değişken olarak; yaş, cinsiyet, meslek, öğrenim durumu, çalışılan bölüm, meslekte görev süresi, şuan çalıştı̆̆ yerdeki görev süresi incelenirken, bağımlı değişken olarak; ötanazi tanımı, ötanazinin yasal boyutu, konu ile ilgili bilgilerini yeterli görme 
durumu ve bilgi kaynakları, ötanazi uygulanması istemine tanık olup olmadıkları, ötanaziyle ilgili beklentileri ve ötanaziye bakışları incelenmiştir.

\section{Veri Toplama Araçları ve Uygulaması}

Verilerin toplanmasında literatürlerden yararlanılarak 30 sorudan oluşan anket formu kullanılmıştır. ${ }^{10}$ ${ }^{-16}$ Çalışmaya katılmayı kabul eden hemşire ve hekimlere anket formları elden verilerek anket sorularını cevaplandırmaları istenmiş ve ihtiyaç halinde sorularla ilgili gerekli açıklamalar yapılmıştır. Ça1ışmanın yapılabilmesi için Başkent Üniversitesi Tıp ve Sağlık Bilimleri Araştırma Kurulu tarafından gerekli izinler alınmıştır.

\section{Verilerin Değerlendirilmesi}

Toplanan verilerin analizi bilgisayardan Statistical Package for Social Sciences (SPSS) 11,5 programında yapılmıştır. Elde edilen veriler bütün değişkenler için tanımlayıcı istatistikler ortalama, sayı ve yüzde dağılımları incelenmiş, bağımsız değişkenler ile bağımlı değişkenler arasındaki ilişki ki kare testi uygulanarak değerlendirilmiștir.

\section{BULGULAR}

Tablo 1'de araştırmaya katılan grubun demografik özelliklerine göre dağılımları incelenmiștir. Araștırmaya katılanların \%59.7'sini hemșireler, \%40.3'nü ise hekimler oluşturmaktadır. \%69.5'ini 25-30 yaş

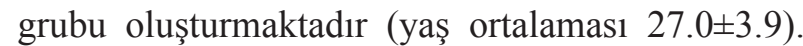
Cinsiyet yönünden yarıdan fazlasının kadınlardan $(\% 67,5)$ oluştuğu, çoğunluğunun bekâr olduğu (\%77.3), yaklaşık üçte ikisinin fakülte/yüksekokul mezunu $(\% 52,6)$ olduğu belirlenmiştir.

Araştırma grubunun \%41.6'sının cerrahi servisinde, \%32.2'sinin yoğun bakımlarda ve $\% 27.3$ 'ünün dahiliye servislerinde çalıştıkları belirlenmiştir. Meslekteki görev sürelerinin ortalaması yıl olarak incelendiğinde $4.2 \pm 2.7$, şuan ki bölümde çalışma süreleri ise $2.3 \pm 3.0$ 'dir.
Tablo 1. Araştırmaya Katılanların Demografik Özelliklerine Göre Dağılımı

\begin{tabular}{|c|c|c|}
\hline Sosyo-demografik Özellikler & $\mathrm{n}$ & $\%$ \\
\hline \multicolumn{3}{|l|}{ Meslek } \\
\hline Hemşire & 92 & 59.7 \\
\hline Hekim & 62 & 40.3 \\
\hline \multicolumn{3}{|l|}{ Yaş Grupları } \\
\hline 19-24 & 30 & 19.5 \\
\hline $25-30$ & 107 & 69.5 \\
\hline$>30$ & 17 & 11.0 \\
\hline \multicolumn{3}{|l|}{ Cinsiyet } \\
\hline Kadın & 104 & 67.5 \\
\hline Erkek & 50 & 32.5 \\
\hline \multicolumn{3}{|l|}{ Medeni Durum } \\
\hline Evli & 35 & 22.7 \\
\hline Bekar & 119 & 77.3 \\
\hline \multicolumn{3}{|l|}{ Eğitim durumu } \\
\hline Sağlık Meslek Lisesi & 8 & 5.2 \\
\hline Yüksekokul/Fakülte & 81 & 52.6 \\
\hline Yüksek Lisans ve üzeri & 65 & 42.2 \\
\hline Toplam & 154 & 100.0 \\
\hline
\end{tabular}

Tablo 2. Hemşire ve Hekimlerin ve Ötanaziyi Tanımlama Durumları

\begin{tabular}{|c|c|c|c|c|c|c|}
\hline \multirow{2}{*}{ Ötanazinin Tanımı* } & \multicolumn{2}{|c|}{ Hemşire } & \multicolumn{2}{|c|}{ Hekim } & \multicolumn{2}{|c|}{ Toplam } \\
\hline & $\mathrm{n}$ & $\%$ & $\mathrm{n}$ & $\%$ & $\mathrm{n}$ & $\%$ \\
\hline $\begin{array}{l}\text { Letal bir ajanın medikal } \\
\text { yoldan uygulanması }\end{array}$ & 39 & 42.4 & 31 & 50.0 & 70 & 45.3 \\
\hline $\begin{array}{l}\text { Hastanın yaşatılması için } \\
\text { çaba harcanmaması }\end{array}$ & 6 & 6.5 & 6 & 9.7 & 12 & 7.7 \\
\hline $\begin{array}{l}\text { Tedavinin durdurulması/ } \\
\text { yavaşlatılması }\end{array}$ & 20 & 21.7 & 6 & 9.7 & 25 & 16.2 \\
\hline Hepsi & 27 & 29.4 & 19 & 30.6 & 46 & 29.8 \\
\hline \multicolumn{7}{|l|}{$\begin{array}{l}\text { Ötanazi Konusundaki Dü- } \\
\text { şünceler** }\end{array}$} \\
\hline $\begin{array}{l}\text { Cinayettir / kasten adam } \\
\text { öldürmektir }\end{array}$ & 15 & 16.3 & 12 & 19.4 & 27 & 17.5 \\
\hline $\begin{array}{l}\text { Doğaya/ yaratana/ evrene } \\
\text { karşı gelmektir }\end{array}$ & 24 & 26.1 & 10 & 16.1 & 34 & 22.1 \\
\hline Tıbbi bir uygulamadır & 38 & 41.3 & 23 & 37.1 & 61 & 39.6 \\
\hline $\begin{array}{l}\text { Hastanın yaşamak kadar } \\
\text { ölmek de hakkıdır }\end{array}$ & 57 & 62.0 & 38 & 54.4 & 95 & 61.8 \\
\hline
\end{tabular}

* Hemşire ve hekim sayıları üzerinden yüzde alınmıştır.

* Birden fazla seçenek işaretlenmiş olup hemşire ve hekim sayıları üzerinden yüzde alınmıştır. 
Tablo 2'de hemşirelerin ve hekimlerin ötanaziyi tanımlama durumları incelenmiștir. Hemşirelerin $\% 42.4$ 'ünün, hekimlerin \%50'sinin ötanaziyi "letal (ölümcül) bir ajanın medikal yoldan uygulanması", hemşirelerin \%6.5'inin, hekimlerin \%9.7'sinin "hastanın yaşatılması için çaba harcanmaması", hemşirelerin \%21.7'sinin, hekimlerin \%9.7'inin "tedavinin durdurulması/yavaşlatılması", hemşirelerin \%29.4'ünün, hekimlerin \%30.6'sının “tanımların hepsi" şeklinde ifade ettikleri saptanmıştır. Hemşire ve hekimlerin ötanazi konusundaki düşünceleri incelendiğinde, genel olarak hemşirelerin \%41.3'ünün, hekimlerin \%37.1'inin ötanaziyi “tıbbi bir uygulama", hemşirelerin \%62'sinin, hekimlerin \%54.4'ünün "hastanın yaşamak kadar ölme hakkının olduğu şeklinde görüş bildirdikleri belirlenmiştir.

Tablo 3. Hemşire ve Hekimlerin Ötanaziye İlişkin Yaklaşımlarının Dağılımı*

\begin{tabular}{|c|c|c|c|c|}
\hline \multirow{2}{*}{$\begin{array}{l}\text { Ötanazi isteği ile karşılaşma } \\
\text { durumu }\end{array}$} & \multicolumn{2}{|c|}{ Hemşire } & \multicolumn{2}{|c|}{ Hekim } \\
\hline & $\mathrm{n}$ & $\%$ & $\mathrm{n}$ & $\%$ \\
\hline Hayır & 63 & 68.5 & 45 & 72,6 \\
\hline Evet & 29 & 31.5 & 17 & 27,4 \\
\hline \multicolumn{5}{|l|}{ Aktif ötanaziyi destekleme } \\
\hline Evet & 29 & 31.5 & 26 & 41,9 \\
\hline Hayır & 40 & 43.5 & 20 & 32,3 \\
\hline Kararsız & 23 & 25.0 & 16 & 25,8 \\
\hline \multicolumn{5}{|l|}{ Pasif ötanaziyi destekleme } \\
\hline Evet & 40 & 43.5 & 32 & 51.6 \\
\hline Hayır & 32 & 34.8 & 13 & 21.0 \\
\hline Kararsız & 20 & 21.7 & 17 & 27.4 \\
\hline \multicolumn{5}{|c|}{ Yakınları için ötanaziyi isteme durumu } \\
\hline Evet & 12 & 13.0 & 21 & 25.0 \\
\hline Hayır & 46 & 50.0 & 36 & 58.1 \\
\hline Kararsız & 34 & 37.0 & 6 & 16.9 \\
\hline \multicolumn{5}{|c|}{ Kendisi için ötanaziyi isteme durumu } \\
\hline Evet & 29 & 31.5 & 27 & 43.5 \\
\hline Hayır & 34 & 37.0 & 15 & 24.2 \\
\hline Kararsız & 29 & 31.5 & 20 & 32.3 \\
\hline \multicolumn{5}{|c|}{ Ötanazi hakkında bilgi durumları } \\
\hline Bilgim var & 84 & 91.3 & 58 & 93.5 \\
\hline Bilgim yok & 8 & 8.7 & 4 & 6.5 \\
\hline Toplam & 92 & 100.0 & 62 & 100.0 \\
\hline
\end{tabular}

* Hemşire ve hekim sayıları üzerinden yüzde alınmıştır. Tablo 3'de hemşirelerin \%68.5'inin, hekimlerin \%72.6'sının ötanazi isteğiyle "karşılaşmadığı" belirlenmiştir $(p=0.683)$. Hemşirelerin \%31.5'i, hekimlerin \%41.9'u “aktif ötanazinin uygulanmas1 gerektiğini”' $(p=0.312)$, hemşirelerin $\% 43.5$ 'i, hekimlerin \%51.6's1 "pasif ötanazinin uygulanmas1 gerektiğini" düşünmektedir $(p=0.179)$. Hemşirelerin $\% 50$ 'sinin, hekimlerin \%58.1'inin "yakınlarına ötanazi uygulanmasını kabul etmedikleri” saptanmıștır $(\mathrm{p}=0.083)$. Hemşirelerin \%31.5'inin ve hekimlerin \%43.5'inin "kendileri için ötanazi uygulamasını kabul ettikleri” saptanmıştır ( $\mathrm{p}=0.185)$. Hemşirelerin \%91.3'ü, hekimlerin \%93,5'i ötanazi hakkında bilgisi olduğunu belirtmişlerdir $(\mathrm{p}=0.683)$.

Hemşire ve hekimlerin ötanazi hakkında elde ettikleri bilgilerin kaynakları incelendiğinde, hemşirelerin \%82,6'sının, hekimlerin \%79'unun mesleki okul eğitimi sırasında, hemşirelerin \%57.6 sının, hekimlerin \%50'sinin medya-basın kuruluşlarından, en az oranda da hizmet içi eğitim-konferanslardan bilgi edindikleri saptanmıştır.

Çalıştıkları birime göre ötanaziyi destekleme durumu karşılaştırıldığında, aktif ötanazinin olması gerektiğini düşünenlerin \%40.3'ü, yoğun bakımda, $\% 33.3$ 'ü cerrahi servisinde, \%26.4'ü dahiliye servisinde çalışmaktadır. Yoğun bakımda çalışanların ötanaziyi kabul etme oranları daha yüksektir ancak aralarında istatistiksel olarak anlamlı bir farkl1lık yoktur ( $p>0.05$ ). Çalışmaya katılanlar arasında yaş grubu düşük olanlar $\left(\mathrm{x}^{2}=18.959, \mathrm{p}=0.001\right)$ ve bekârların $\left(\mathrm{x}^{2}=8.817, \mathrm{p}=0.032\right)$ ötanaziye karşı olma durumu daha yüksektir. Diğer değişkenlerle ötanaziye bakış açıları arasında anlamlı bir ilişki bulunmamış$\operatorname{tir}(\mathrm{p}>0.05)$.

Tablo 4'de araştırmaya katılanların ötanaziyi istememe nedenleri incelendiğinde genellikle hemşirelerin \%38'inin, hekimlerin \%39'unun "vicdani rahatsızlık duyacağı"; hemşirelerin \%20.7'sinin, hekimlerin \%24.2'sinin "tıbbın insanları yaşatmak için var olması gerektiği”; hemşirelerin \%12.0'inin, hekimlerin \%14.5'inin "dini nedenlerden" dolay1 ötanaziye karşı oldukları saptanmıştır. Hemşire ve hekimlerin ötanazi uygulamasını kabul etme nedenleri arasında en fazla dikkati çeken hemşirelerin \%30.4'ü, hekimlerin \%37.1'inin "ac1 çekmemek" için ötanaziyi kabul ettikleri belirlenmiştir. 
Tablo 4. Hemşire ve Hekimlerin Ötanaziye Karşı Olma Nedenleri ${ }^{*}$

\begin{tabular}{|c|c|c|c|c|}
\hline \multirow{2}{*}{ Ötanaziye Karşı Olma Nedenleri } & \multicolumn{2}{|c|}{ Hemşire } & \multicolumn{2}{|c|}{ Hekim } \\
\hline & $\mathrm{n}$ & $\%$ & $\mathrm{n}$ & $\%$ \\
\hline Vicdani rahatsızlık duyma & 35 & 38.0 & 23 & 39.0 \\
\hline Dini nedenler & 15 & 16.3 & 9 & 14.5 \\
\hline $\begin{array}{l}\text { Tıbbın insanları yaşatmak için var } \\
\text { olması }\end{array}$ & 19 & 20.7 & 15 & 24.2 \\
\hline $\begin{array}{l}\text { Ölümü hızlandırmanın anlamsız- } \\
\text { ıı̆ı }\end{array}$ & 7 & 7.6 & 3 & 4.8 \\
\hline Tıpta yeni gelişmelerin beklentisi & 11 & 12.0 & 5 & 8.1 \\
\hline Yasal yükümlülükler & 10 & 10.9 & 12 & 19.3 \\
\hline \multicolumn{5}{|l|}{ Ötanaziyi Kabul Etme Nedenleri } \\
\hline $\begin{array}{l}\text { Bakımımla ilgili kişilere sıkıntı ver- } \\
\text { memesi }\end{array}$ & 19 & 20.7 & 19 & 30.6 \\
\hline Acı çekmemesi & 28 & 30.4 & 23 & 37.1 \\
\hline $\begin{array}{l}\text { Tedavisi olmayan hastalıkların } \\
\text { varlığı }\end{array}$ & 19 & 20.7 & 13 & 21.0 \\
\hline $\begin{array}{l}\text { Yatağa bağımlı yaşamanın anlam- } \\
\text { sızlığı }\end{array}$ & 19 & 20.7 & 18 & 29.0 \\
\hline Aileye/ devlete maddi yük olması & 21 & 22.9 & 12 & 19.4 \\
\hline
\end{tabular}

* Birden fazla seçenek işaretlenmiş olup hemşire ve hekim sayıları üzerinden yüzde alınmıştır.

Hemşirelerin \%41.3'ü, hekimlerin \%48.4'üülkemizde ötanazinin "yasallaşmasını istemedikleri" belirlenmiştir ( $\mathrm{p}=0.682$ ). Hemşirelerin \%66.3'ünün, hekimlerin \%66.1'inin "prognozu kötü, şiddetli ağnı çeken malign hastalığı olan"; hemşirelerin \%52.2'sinin, hekimlerin \%45.2'sinin "yaşamını yaşam destek sistemine bağlı olarak sürdüren"; hemşirelerin \%21.7'sinin ve hekimlerin \%29'unun "yatağa bağımlı olup kendi ihtiyaçlarını karşılayamayan"; hemşirelerin \%72.8'inin, hekimlerin \%62.9'unun "beyin ölümü gerçekleşen"; hemşirelerin \%51.2'sinin, hekimlerin \%41.9'unun "terminal dönemde bulunan hastalara" ötanazinin uygulanabileceğini düşündükleri saptanmıştır.

Ötanazinin yasallaşması durumunda uygulamayı kimin yapacağına dair hemşire ve hekimlerin düşünce durumları incelenmiştir. Hemşirelerin \%32.6's1, hekimlerin \%29'u "hekim"; hemşirelerin $\% 8.7$ 'si, hekimlerin \%6.5'u "hemşire"; hemşirelerin \%7.6's1, hekimlerin \%11.3'ü "hastanın kendisi”; hemşirelerin \%6.5'i, hekimlerin \%3.2'si "hastanın ailesinden bir kişi"; hemşirelerin \%65.2'si, hekimlerin \% 75.6'sı "yasaların belirlediği bir ekip tarafın- dan" uygulamanın yapılabileceğini belirtmișlerdir. Hemşirelerin \%6.6'sının ise "bu iş için gönüllü insanların ve hekim eşliğinde hastanın kendisinin uygulamayı yapabileceğini” söyledikleri saptanmıştır.

Yasal düzenleme yapıldığ 1 takdirde ötanazi ekibinde yer almayı düșünür müsünüz? sorusuna, hemșirelerin \%3.3'ünün, hekimlerinin \%9.7'sinin "aktif ötanazide"; hemşirelerin \%9.8'inin, hekimlerin \%14.5'inin "pasif ötanazide"; hemșirelerin \%72.8'inin, hekimlerin \%67.7'sinin ise "görev almak istemediği" belirlenmiştir $(\mathrm{p}=0.202)$. Ötanazinin yasal olarak uygulanmaya başlanırsa istismar edilip edilemeyeceğine dair düşünce durumları incelendiğinde hemșirelerin \%71.7'si, hekimlerin \%72.6's1 "istismar edilebilir" şeklinde yanıt vermişlerdir $(\mathrm{p}=0.716)$. Ötanazinin yasal olarak uygulanması durumunda hangi konularda istismar edilebileceğine dair düşünceler incelendiğinde, hemşirelerin \%32.6'sının, hekimlerin \%14.5'inin "tıbbi gelişmeleri engellemesi"; hemşirelerin \%33.7'sinin, hekimlerin \%37.1'inin "kişiler arası eşitsizliklere yol açması"; hemşirelerin \%59.8'inin, hekimlerin \%67.7'sinin "miras konusunda"; hemşirelerin $\% 28.3$ 'ünün, hekimlerin \%37.1'inin "sağlık personelini tembelliğe itmesi"; hemşirelerin \%63'ünün, hekimlerin \%74.2'sinin "ailenin tedavi masraflarından kurtulmak amaciyla ötanazinin istismar edilebileceğini" düşündükleri belirlenmiştir $(p=0.354)$. Çalışmada ötanazinin ülkemizde belirli durumlarda uygulanıp uygulanmadığına yönelik düşünce durumları incelenmiştir. Hemşirelerin \%57.6's1, hekimlerin \%69.4'ü "pasif ötanazinin uyguland1ğına inandığını"; hemşirelerin \%14.1'i, hekimlerin \%12.9'u "hiçbir durumda uygulanmadığına inandığını"; hemşirelerin \%21.7'si, hekimlerin \%16.1'i ise "fikrinin olmadığını" belirtmiştir $(p=0.454)$.

\section{TARTIŞMA}

\section{Hemşire ve Hekimlerin Ötanazi Hakkındaki Bilgileri}

Dünyada ötanazi konusunda tartışmalar devam ederken ülkemizde de konuyla ilgili araştırmalar yapılmaktadır. Özkara ve ark.'nın, ${ }^{16}$ yaptığ 1 çalışmada ankete katılan hekimlerin $\% 88$ 'i ötanaziyi "günümüz tıbbının iyileşme umudu taşımadığı, ilerleyici, acı verici ve öldürücü bir hastalığa yakalanan kişi için; kaçınılmaz ve ızdırap verici bir süreç olan ölümün kendi isteğiyle daha uygun şartlarda ve acısız olarak bir hekim yardımıyla gerçekleştirilmesidir" 
șeklinde tanımladıkları görülmüștür. Iș1khan'ın, ${ }^{17}$ yaptığı çalışmada katılanların \%84'ü ötanaziyi; tıbbın iyileştiremediği ve yaşamın hastanın kendisi için çok 1zdıraplı ve eziyetli olduğu durumlarda hasta istemi ile yaşama son verilmesi olarak; \%5.2'sinin ise yaşamından umut kesilen hastaların tedavilerinin kendi rızaları ile sona erdirilmesi şeklinde tanımladıkları görülmüştür. Hem çalışmamızda hem de Karagöz ve ark.'nın, ${ }^{11}$ çalışmasında ötanazi tanımının benzer olduğu görülmektedir.

Özler'in, ${ }^{18}$ yaptığ 1 çalışmada hemşirelerin \%55.2'sinin, Işıkhan'ın (2002) yaptığı çalışmada sağlık personelinin \%28.8'inin, Doğan ve arkadaşlarının, ${ }^{19}$ yaptığı çalışmada hemşirelerin yarıdan fazlasının ötanazi konusunda yeterli bilgisinin olduğu saptanmıştır. Çalışmamızda hemşirelerin \%91.3'ü, hekimlerin \%93.5'i ötanazi hakkında yeterli bilgiye sahibi olduklarını belirtmişlerdir. Nehir ve ark.'nın, ${ }^{15}$ çalışmasında ötanazi hakkında bilgiye sahibi olma oranı \%89.1 olup çalışmamızla benzerlik göstermektedir.

Işıkhan'ın, ${ }^{17}$ yaptığı çalışmada sağlık personelinin \%45,8'inin medya-basın aracılığ \%36.3'ünün eğitim-öğretim surasında ötanaziye ilişkin bilgi edindikleri görülmüştür. Çalışkan ve ark.'nın, ${ }^{20}$ yaptığı çalışmada ise hekimlerin \%27.7'sinin ötanaziyi medya'dan; \%24.1'inin tıp fakültesi derslerinden ve \%9.6'sının ise mezuniyet sonras1 eğitimlerden öğrendiği görülmüştür. Çalışmamızda da bilgi kaynağı olarak medya ikinci sırada yer almaktadır. Yapılan çalışmalara göre, soyut bir kavram olan ötanazinin anlaşılmasında mesleki eğitimin yanı sıra, medya ve basın kuruluşlarının da önemli bir işlevinin olduğu anlaşılmaktadır.

\section{Hemşire ve Hekimlerin Ötanazi Hakkındaki Düşünceleri}

Erzurum Atatürk Üniversitesi Araştırma ve Uygulama Hastanesinde çalışan sağlık personelinin ötanaziye bakışı isimli araştırmasında, araştırmaya katılan sağlık personellerinden hiçbirinin hastası için aktif ötanaziyi onaylamadığı, pasif ötanaziyi onaylama oranının ise hekimlerde $\% 13.3$, hemşirelerde $\% 5$ olduğu belirlenmiştir ${ }^{21}$. Adana ilindeki çeşitli hastanelerin yoğun bakım ünitelerinde çalışan hemşirelerin ötanazi ile ilgili görüşlerinin incelendiği çalışmada hemşirelerin \%55.9'unun ötanazi için "insan/hasta hakkıdır" yönünde cevap verdikleri görülmüştür. ${ }^{13}$ Çalışmamızda hemşirelerin \%62'si; hekimlerin ise \%54.4'ü "hastanın yaşamak kadar ölmeye de hakk1nın" olduğunu yönünde görüș bildirseler de hekim ve hemşirelerin üçte ikisi aktif ötanaziyi desteklememektedirler. Özkara ve ark.'nın, ${ }^{16}$ dışında (\%48), ülkemizde yapılan diğer çalışmalarda ötanaziyi destekleme durumu çalışmamıza oranla daha düşük bulunmuştur (\%20-\%30)..$^{10,12,13,21}$ Yurt dışında yapilan çalışmalarda ötanaziyi destekleme oranı $\% 60-\% 90$ arasında değişmektedir. ${ }^{22-24}$

Çalışmamızda, hemşire ve hekimler genelde aktif ötanazinin uygulanmaması gerektiğine inansalar da yaklaşık yarısı pasif ötanaziyi kabul edilebilir görmüşlerdir. Ancak hekim ve hemşireler, hiçbir şekilde tedavi şansları olmadığında acı çekmemeleri için bunu onaylayacaklarını" belirtmişlerdir. Ötanaziye onay göstermeyen hekim ve hemşireler en fazla "vicdani rahatsızlık duymaları" nedeniyle aktif ötanaziyi karşı olduklarını belirtmişlerdir. Yapılan diğer çalışmalarda da benzer bulgular dikkati çekmektedir. ${ }^{21-25}$

Çalışmamızda, hemşire ve hekimlerin çoğu (\%70.1) mesleki yaşamları boyunca hasta veya ailesinin ötanazi isteği ile karşılaşmadıklarını belirtmiş̧tir. $\mathrm{Bu}$ sonucun araştırmaya katılanların \%69.5'inin genç yaş grubunda olması ve çalışanların \%67.5' inin toplam meslekte görev süresinin 1-2 yıl arasında değişmesinden kaynaklandığı düşünülmüştür. Karagöz ve ark.'nın, ${ }^{11}$ çalışmasında hekimlerin \%17'sinin ötanazi isteği ile karşılaştı̆̆ belirtilmiştir. Yurt dışında yapılan çalışmalarda özellikle onkoloji ve yoğun bakım hastalarında bu taleple karşılaş̧ıkları belirtilmiştir. ${ }^{22-24}$

Çalışmamızda ötanaziye sıcak bakanların kendisi ve yakınları için de ötanazi uygulamasını kabul edilebilir gördükleri belirlenmiştir. Literatürde benzer bulgulara rastlanmaktadır. ${ }^{12,}{ }^{17,19-21}$ Brzostek' in, ${ }^{25}$ yaptığı çalışmada katılımcıların \%26'sının kendileri için ötanazi uygulanmasını kabul ederken; \%38'inin kabul etmediğini ve \%33'ünün ise kararsız olduğu görülmüştür.

Çalışmamızda ötanazi uygulamasının Türkiye' de yasallaşmasını isteyenlerin oranı hekimlerde \%48.4, hemşirelerde daha az olmakla birlikte \%41.3'dür. Işıkhan'ın, ${ }^{17}$ yaptığ 1 çalışmada sağlık personelinin \%38.5'inin, Özkara ve ark.'nın, ${ }^{17}$ yaptığ 1 çalışmada hekimlerin \%47'sinin, Karagöz ve ark.'nın, ${ }^{11}$ yaptı̆̆ 1 çalışmada hekimlerin $\% 50$ 'sinin ötanazinin yasallaşmasını istediği belirlenmiştir. Diğer çalışmalarda ise ötanazinin ülkemizde yasal- 
laşmasının sağlık çalıșanları tarafından büyük oranda istenmediği yönünde bir sonuç bulunmuştur. ${ }^{15,19}$ Yurt dışında yapılan diğer çalışmalarda yasal değişiklerin yapılmasını isteme oranı $\% 60-\% 70$ arasında değişmektedir. ${ }^{22-24,26}$

Çalışmamızda ötanazinin yasallaşması durumunda uygulamanın kimlere yapılması gerektiği sorusuna katılanların çoğunluğu (\%68.8) "beyin ölümü” olanlar şeklinde yanıt vermişlerdir. Diğer çalışmalarda da benzer bulgulara rastlanmaktadır. ${ }^{13,17}$ Çalışmamızda, ötanazi uygulamasını kimin yapmas1 gerektiğine yarıdan fazlası "yasaların belirlediği bir ekip" cevabını verirken, \%31.2'sinin ise hekim cevabını verdiği saptanmıştır. Işıkhan'ın, ${ }^{17}$ yaptığ 1 çalışmada sağlık personelinin \%36.8'inin ötanazi kararını hastanın kendisinin, \%21.5'inin hastanın ailesinin vermesi gerektiğini düşünmüşlerdir. Kaya ve ark. ${ }^{12}$ ve Özler'in, ${ }^{18}$ çalışmasında sağlık personelinin çoğunluğu ötanazi uygulamasını hekimler tarafindan yapılması gerektiğini bildirmişlerdir.

Çalışmamızda çalışanların yaklaşık yarısı ötanazinin yasallaşmasını istedikleri halde yasal düzenleme yapıldığ 1 takdirde ötanaziyi uygulayan ekip içerisinde görev almayı istemediklerini belirtmişlerdir (\%70.8). Benzer olarak Özler'in, ${ }^{18}$ ve Doğan'nın, ${ }^{19}$ çalışmasında hemşirelerin \%70'i yasal düzenleme yapılsa bile ötanazide görev almak istemediklerini belirtmiştir. Başka bir çalışmada hemşirelerin $\% 65$ 'i ötanazi yasal hale gelirse, aktif ötanazide gönüllü olarak hekimlerle birlikte çalışabileceklerini belirtmişlerdir ${ }^{26}$

Çalışmamızda ötanazi yasal olarak uygulanmaya başlanırsa katılanların \%72.1'i istismar edilebileceğini belirtmişlerdir. İstismar edilebileceği düşünülen konular arasında $\% 67.5$ 'ini ailenin tedavi masraflarından kurtulmak istemesi ve miras oluşturmaktadır. Kumaş'ın ${ }^{13}$ yaptığı çalışmada da benzer yanıtlar verilmiştir. Işıkhan'ın. ${ }^{17}$ yaptığ 1 çalışmada să̆lık personellerinin \%80.8'inin ötanazinin istismar edilebileceğini düşündükleri görülmüştür. $\mathrm{Bu}$ konuların nedenleri arasında katılanların $\% 31,9$ 'unun miras ve \%30'unun ise ailenin tedavi masraflarından kurtulma isteği olduğu görülmüştür. Çalışmamızda ülkemizde belirli durumlarda ötanazi uygulanıyor mu? Sorusuna çalışanların \%62.3'ünün pasif ötanazinin uygulandığına inandıkları saptanmıştır. Literatürde, ülkemizde ötanazinin belirli durumlarda uygulandığına katılanların oranı \%30$\% 70$ arasında değişmektedir. ${ }^{13.12 .17 .18}$

\section{SONUÇ VE ÖNERILER}

Hemşire ve hekimlerin ötanazi uygulamasına yarısı sıcak bakarken diğer yarısı sıcak bakmamaktadır. Hemşire ve hekimlerin önemli bir kısmı yasam desteklerinin çekilmesi anlamında pasif ötanaziyi kabul edilebilir bulmakta iken, aktif ötanaziye yarıdan fazlası katılmamaktadır. Ötanazi uygulamasında vicdani rahatsızlık duyacaklarını ve tıbbın insanları yaşatmak için var olması gerektiğini düşünmeleri nedeni ile ötanaziyi büyük oranda onaylamamakla birlikte iyileşme olasıllı̆̆ bulunmayan ve dayanılmaz ağrılar içinde son günlerini geçirmekte olan bir hastanın ölümünün çabuklaştııılmasını istemesinde yaklaşık yarısının hastanın hakkı olarak savunduğu saptanmıştır. Buna göre araştırmaya katılan sağlık çalışanlarında bu kavramın net oturmadığ 1 ve ikilem yaşayabildikleri belirlenmiştir.

Ayrıca çalışmada ülkemizde yasal olmamasına karşı ötanazinin belli durumlarda uygulandığına inanan hemşire ve hekimler oldukça fazladır. Bu sonuç, ülkemizde bu konunun tartışılması gerektiğinin bir göstergesidir. Elde edilen sonuçlar doğrultusunda; sağlık çalışanlarının mezuniyet öncesi ve sonrası eğitiminde ötanazi konularının daha fazla yer alması ve konunun yasal, etik, politik boyutlarının tartışılması gerektiği söylenebilir. Hizmet içi eğitim programlarının kapsamında, hemşire ve hekimlerin hastanın veya yakınının ötanazi kavramına uyan isteği ile karşılaștığı zaman nasıl bir davranıșta bulunmaları gerektiği, hastanenin bu konu hakkındaki politikalarının net olarak çalışanlarına verilmesi önemli görülmektedir.

\section{KAYNAKLAR}

1. Çobanoğlu N. Kuramsal ve Uygulamalı Tıp Etiği, 1.Basım. Ankara: Eflatun Yayınevi. 2009;23-9.

2. Erdemir A, Erer S ve Öncel Ö. 21. Yüzyıl Başında Yaşama Destek Tedavileri Etik Hukuksal Yönler. 2. Uluslararası Tıp Etiği ve Tıp Hukuku Kongresi-Bildiri Kitabı. (1. Baskı). Ankara: Nobel Yayınevi. 2009.

3. Akdur R, Aydın E. Tıbbi Etik ve Meslek Tarihi, Ankara: 2001;197-200.

4. Özkara, E. Ötanazide Temel Kavramlar ve Güncel Tartışmalar, 1. Bask1, Seçkin Yayıncılık, Ankara:2001;11-14, 19-20, 33-45.

5. İnceoğlu S. Ölme Hakkı, Ayrıntı Yayınları, 1. Basım, İstanbul:1999;40-3.

6. Güven K. Kişilik Hakları ve Ötanazi. Ankara: Nobel Yayın Dağıtım. 2000;6-9. 
7. Demir O. "Hasta Hakları Bildirgesi”, Dünya Hekimler Birliği, Lizbon, 1981 www.hukuki.net (Erişim Tarihi: Nisan 2005).

8. Türk Ceza Kanunu. http://www.tbmm.gov.tr/kanunlar/ k5237.html, (Erişim Tarihi: 3 Mayıs 2010).

9. Türk Deontoloji Tüzüğü. http://www.ttb.org.tr/mevzuat /modules. (Erişim Tarihi: 3 Mayıs 2010).

10. Fadıllığlu Ç ve Yavuz M. "Hemşireler ötanazi hakkında ne düşünüyorlar?” Çınar Dergisi 1997;1.24-8.

11. Karaöz S. Cerrahi hemşireliği ve etik, C.Ü. Hemşirelik Yüksekokulu Dergisi 2000; 4: 45-9.

12. Kaya $H$ ve Akçin $E$. Hemşirelik öğrencilerinin ötanaziye ilişkin görüşleri, Türkiye Klinikleri J Med Ethics 2005; 13.115-9.

13. Kumaş G. Adana İlindeki Çeşitli Hastanelerin Yoğun Bakım Ünitelerinde Çalışan Hemşirelerin Ötanazi Hakkındaki Düşünceleri. Yüksek Lisans Tezi, Çukurova Üniversitesi.2005.

14. Mandıracıŏlu A ve Özsoy SA. Ege Üniversitesi Tıp Fakültesi ve Hemşirelik Yüksekokulu son sınıf öğrencilerinin ötanazi konusuna yaklaşımları, Kriz Dergisi 1995; 3; 270-3.

15. Nehir S, Kardeniz G ve Altıparmak S. Üniversite öğrencilerinin ötanaziye ilişkin düşünceleri: bir yüksekokul örneği, Firat Sağlık Hizmetleri Dergisi 2006; 1: 26- 36.

16. Özkara E, Özdemir Ç, Hancı H, Dalgıç M, Civaner M, Yağmur F. Ankara'da çalışan hekimlerin ötanaziye yaklaşım1, Ankara Üniversitesi Hukuk Fakültesi Dergisi 2002; 51;207-14.

17. Işıkhan H. Kanser hastalarıyla çalışan sağlık personelinin ötanaziye ilişkin düşüncelerinin değerlendirilmesi. Hacettepe Üniversitesi SBE. Yüksek Lisans Tezi. Ankara, 2002.
18. Özler H. Hemşirelerin ötanazi konusuna yaklaşımları ve Osmangazi Üniversitesi hastanesinden örnek bir çalışma. Osmangazi Üniversitesi Sağlık Bilimleri Enstitüsü Deontoloji Anabilim Dalı, Yüksek Lisans Tezi., Eskişehir, 2001.

19. Doğan S, Güler H, Koçak E ve Kelleci M. Sivas ilinde görev yapan bir grup hemşirenin ötanazi uygulamasına ilişkin görüşleri, Kriz Dergisi 1997; 5: 59-63.

20. Çalışkan D, Özdemir O, Akdur R. Abidinpaşa sağlık grup başkanlığı bölgesinde çalışan hekimlerin ötanazi konusunda bilgi tutum davranışları ile ilgili bir çalışma. Türkiye Klinikleri Tıp Etiği-Hukuku-Tarihi Dergisi 2003; 11: 91-101.

21. Bölükbaşı N. Sağlık personelinin ötanaziye bakışı. Uluslar Arası Katılımlı VI. Ulusal Hemşirelik Kongresi Bildirileri Kitabi, GATA Hemşirelik Yüksek Okulu, Ankara, 1998.

21. Winget C, Kapp FT and Yeaworth RC. "Attitudes of cancer patients, their family members and health professionals towards active euthanasia, Europen Journal of Cancer Care", Blackwell Science Ltd, Eur J Cancer Care 2000; 9:16 -21.

22. Verpoort C, Gastmans C, De Bal, N. and Dierckx de Casterle, B. Nurses' attitudes to euthanasia: a review of the literature. Nurs Ethics 2004;11:349-65.

23. Hagelin J, Nilstun T, Hau J, Carlsson HE. Surveys on attitudes towards legalisation of euthanasia: importance of question phrasing, J Med Ethics 2004; 30: 521-3.

24. Oğuz NY, Şenol S, Devrimci Özgüven H, Arıkazan M, Özen AR, Ünal Ş. Ankara'da çalışan hekimlerin ötanazi ile ilgili görüşlerini belirlemeye yönelik bir anket çalışması, 3 P Dergisi 1996; 4: 43-7.

25. Brzostek T, Dekkers W, Zalewski Z, Januszewska A, Górkiewicz M. Perception of palliative care and euthanasia among recently graduated and experienced nurses. Nursing Ethics 2008;15:761 -76. 